УДК 005.5:316.22

DOI: https://doi.org/10.31866/2616-7573.1.2019.170654

КОВАЛЕНКО Слена Ярославівна,

кандидат економічних наук, доцент,

Національна академія керівних кадрів культури і мистецтв,

Київ, Україна, elena.kovalenko.ya@gmail.com

ORCID ID: https://orcid.org/0000-0003-2253-5762

\title{
ТЕОРІЯ ТА ІСТОРІЯ КУЛЬТУРИ МЕХАНІСТИЧНОГО МЕНЕДЖМЕНТУ
}

Анотація. Актуальність. Менеджмент як феномен культури й виключно унікальний об'єкт наукового пізнання займає особливе місце в життєдіяльності суспільства. У міру історичного розвитку людства ускладнюються як організаційні структури, так і культура менеджменту та набір теорій, які їх описують. Проте сучасна наука не враховує того, що кардинальні зміни організаційної реальності відбуваються не постійно, а під час біфуркації цивілізації. Специфічною культурою, яка виникла саме в таких умовах, є механістичний менеджмент, дослідженню якого присвячена ця стаття. Мета і методи. Мета статті - теоретико-історичний аналіз культури механістичного менеджменту, виявлення базових детермінант генезису цієї культури управління та формування основних напрямів іiі розвитку в умовах індустріалізму. Методологічною основою дослідження є діалектичний принцип пізнання, системний, цивілізаційний, історичний підходи до вивчення суспільних явищ і процесів та фундаментальні положення теорії менеджменту. Результати. Визначено об'єктивні передумови становлення культури механістичного менеджменту: європейська наука і механіцизм, що випливає із ньютонівської картини світу - уявлення організаційної реальності як машини, а також атомізм, раціоналізм і соціальний дарвінізм як «природний закон» про міжвидову боротьбу; протестантська етика як виправдання наживи; політекономія, яка представила господарство у вигляді машини, що діє за законами ньютонівської механіки; великі науково-технічні відкриття, що вимагали нових форм організації виробництва. Розкрито сутність, надано порівняльні характеристики й окреслено перспективи подальшого застосування основних напрямів культури механістичного менеджменту: наукової організації праці та управління; адміністративного менеджменту; бюрократії. Висновки та обговорення. Наукова новизна одержаних результатів полягає у виявленні ключових детермінант генезису культури механістичного менеджменту й узагальненні особливостей самостійних напрямів цієї культури, а практичне значення вбачається у розширенні уявлень про теорію та історію світової культури, включивши в них раніше практично не досліджувані в культурно-історичному контексті ідеї, думки, погляди й концепції механістичного менеджменту.

Ключові слова: культура механістичного менеджменту, наукова організація праці й управління, адміністративний менеджмент, бюрократія.

Коваленко Елена Ярославовна, кандидат экономических наук, доцент, Национальная академия руководящих кадров культуры и искусств, Киев, Украина 


\section{Теория и история культуры механистического менеджмента}

Аннотация. Актуальность. Менеджмент как феномен культуры и исключительно уникальный объект научного познания занимает особенное место в жизнедеятельности общества. По мере исторического развития человечества усложняются как организационные структуры, так и культура менеджмента и набор теорий, которые их описывают. Однако современная наука не учитывает того, что кардинальные изменения организационной реальности происходят не постоянно, а во время бифуркации цивилизации. Специфической культурой, возникшей именно в таких условиях, является механистический менеджмент, исследованию которого посвящена эта статья. Цель и методыл. Цель статьи - теоретикоисторический анализ культуры механистического менеджмента, выявление базовых детерминант генезиса этой культуры управления и формирование основных направлений ее развития в условиях индустриализма. Методологической основой исследования являются диалектический принцип познания, системный, цивилизационный, исторический подходы к изучению общественных явлений и процессов и фундаментальные положения теории менеджмента. Результаты. Определены объективные предпосылки становления культуры механистического менеджмента: европейская наука и механицизм, вытекающий из ньютоновской картины мира - представление организационной реальности как машины, а также атомизм, рационализм и социальный дарвинизм как «естественный закон» о межвидовой борьбе; протестантская этика как оправдание наживы; политэкономия, представившая хозяйство в виде машины, действующей по законам ньютоновской механики; великие научно-технические открытия, потребовавшие новых форм организации производства. Раскрыта сущность, предоставлены сравнительные характеристики и очерчены перспективы последующего применения основных направлений культуры механистического менеджмента: научной организации труда и управления; административного менеджмента; бюрократии. Bblводы и обсуждение. Научная новизна полученных результатов заключается в выявлении ключевых детерминант генезиса культуры механистического менеджмента и обобщении особенностей самостоятельных направлений этой культуры, а практическое значение усматривается в расширении представлений о теории и истории мировой культуры, включив в них ранее практически не исследуемые в культурно-историческом контексте идеи, мысли, взгляды и концепции механистического менеджмента.

Ключевые слова: культура механистического менеджмента, научная организация труда и управление, административный менеджмент, бюрократия.

Kovalenko Yelena, $\mathrm{PhD}$ (Economics), Associate Professor, National Academy of Managerial Staff of Culture and Arts, Kyiv, Ukraine

\section{Theory and history of culture mechanistic management}

Abstract. Actuality. Management as a phenomenon of culture and an exclusively unique object of scientific knowledge occupies a special place in the life of society. As historical development of mankind is complicated as organizational structures, as well as the culture of management and a set of theories that describe them. However, modern science does not take into account that radical changes in organizational reality occur not continuously, but during the bifurcation of civilization. A specific culture that arose precisely in such conditions is mechanistic management, the study of which is devoted to this article. Purpose and methods. The purpose of the article is a theoretical and historical analysis of the culture of mechanistic management, the identification of the 
basic determinants of the genesis of this management culture and the formation of the main directions of its development in conditions of industrialism. The methodological basis of the research is the dialectical principle of cognition, systemic, civilization, historical approaches to the study of social phenomena and processes, and the fundamental provisions of the theory of management. Results. The objective preconditions of the formation of a culture of mechanistic management are determined: European science and mechanism arising from the Newtonian picture of the world - the presentation of organizational reality as a machine, as well as atomism, rationalism and social Darwinism as a "natural law" about inter-species struggle; Protestant ethics as a justification of profit; political economy, which introduced the economy in the form of a machine operating under the laws of Newtonian mechanics; great scientific and technical discoveries, demanding new forms of organization of production. The essence of the article is given, comparative characteristics are given and prospects of further application of the main directions of culture of mechanistic management: scientific organization of labor and management are outlined; administrative management; the bureaucracy. Conclusions and discussion. Scientific novelty of the obtained results consists in identifying the key determinants of the genesis of the culture of mechanistic management and generalization of the peculiarities of the independent trends of this culture, and practical significance is seen in expanding the perceptions of the theory and history of world culture, including in them previously practically not explored in the cultural-historical context ideas, thoughts, views and concepts of mechanistic management.

Keywords: culture of mechanistic management, scientific organization of labor and management, administrative management, bureaucracy.

\section{1. Актуальність проблеми Actuality of problem}

Серед багатьох теоретичних концепцій, що характеризують різні сторони людського буття, особливе місце займає узагальнення уявлень про менеджмент як феномен культури. Справа в тому, що менеджмент виключно унікальний об'єкт наукового пізнання. За умови максимально широкого підходу під ним ми розуміємо культурний процес перетворення суспільного хаосу на порядок, а в дещо вужчому та більш конкретному розумінні - це діяльність, яка спрямована на забезпечення цілісності й життєздатності організацій у конкурентному середовищі. Існує і безліч інших підходів до розуміння феномену менеджменту, що інтерпретують по-своєму різні грані цього складного соціального явища.

У міру історичного розвитку людства безперервно ускладнюються як структура організацій і технологія процесів, що в них протікають, так і культура менеджменту та набір теорій, які їх описують. Проте кардинальні зміни відбуваються не постійно, а переважно у точках біфуркації цивілізаціїперіодах переходу її від старого циклу до нового й формування принципово іншого соціального порядку. Саме в такі історичні періоди змінюється майже все: устрій суспільства, форми й методи його організацій, культура та мистецтво управління, а також загальнонаукова картина світу, на основі 
якої відбувається переосмислення і переоцінка дійсності, нове сприйняття й розуміння людських відносин та менеджменту.

Виходячи з цього, можна стверджувати, що біфуркація цивілізації $\epsilon$ причиною не тільки кардинальних трансформацій суспільства, його підсистем і різних організацій, але й пусковим механізмом управлінських революцій - радикальної зміни парадигми менеджменту, поворотним моментом у культурі управління, переходом іiї до якісно іншого стану. Отже, кожний етап еволюції суспільства, кожна історична епоха пропонують свої правила взаємовідносин суб'єктів управління, способи організації управлінського процесу, свою особливу культуру менеджменту.

Такою специфічною культурою управління, яка виникла в умовах пізньосередньовічної біфуркації цивілізації - системної кризи, що охопила епоху Відродження, Реформацію і Просвітництво й завершилася народженням нового циклу світової цивілізації - індустріального суспільства, $є$ культура механістичного менеджменту. Ця управлінська культура зіграла важливу роль у процесах модернізації життєдіяльності людей i, всупереч прогнозам, не втратила своєї значущості та «живучості» сьогодні - вже в умовах пізньоіндустріальної біфуркації змінення картини світу й формування базових елементів інформаційного суспільства, що становить неабиякий інтерес для сучасного філософського і наукового аналізу.

Стан вивчення проблеми. Дослідження концепцій механістичного менеджменту, в історико-культурологічному контексті, потрібно розпочати з ретельного аналізу першоджерел окресленої проблематики, що дозволить виявити низку вихідних положень, які забезпечують можливість наукового розгляду еволюції цих концепцій. Механістичні ідеї виникли не спонтанно, а мали солідну, багатовікову передісторію, що відображає реальні зміни, які відбувалися в соціумі. Проведений нами аналіз дозволив виявити доіндустріальний, індустріальний і постіндустріальний етапи еволюції механістичних поглядів у контексті теорії менеджменту. В розгорнутому вигляді цей результат аналізу сучасного стану вивчення досліджуваної проблеми можна представити наступним чином.

Доіндустріальний етап (XVII-XVIII ст.) характеризується зародженням самої механістичної ідеї як такої (Гоббс, 2000; Декарт, 2017; Лейбниц, 1983; Ньютон, 1989) і формуванням передумов, перших понять та дослідницьких підходів до механістичного менеджменту (Милль, 2007; Смит, 2016; Сен-Симон, 2015; Babbage, 2009; Marshall, 2015; Owen, 2015; Trentowski, 1843; Ure, 1835). Носіїв цих ідей часто називають «пророками», «предтечами» механіцизму.

Індустріальний етап (кін. XIX - серед. XX ст.), на якому формується загальний концептуальний замисел, що визначив суть i «дух» механістичного менеджменту як такого; розробляються його основні змістовні частини: наукова організація праці (Тейлор, 1992; Gantt, 2017; Gilbreth \& Gilbreth, 2012; Emerson, 1912); адміністрування (Файоль, 1992; Gulick, 
1948; Mooney \& Reiley, 1931; Urwick, 1944); бюрократія (Вебер, 2010; Мертон, 2006; Gouldner, 1954; Downs, 1967; Grozier, 1963).

Постіндустріальний етап (з кін. XX ст. до цього часу), який виник у результаті комп'ютерної революції і входження суспільства в інформаційну еру. На цьому етапі здійснюються спроби корегування механістичних концепцій менеджменту шляхом їх теоретичної добудови й заповнення «білих плям», а також ув'язування і адаптації до нових реалій (Друкер, 2007; Мартинишин \& Коваленко, 2017, 2018a, 2018b; Минцберг, 2011; Сенге, 2014; Флорида, 2012; Hamel, 2007; Pink, 2015 та багато ін.).

Крім цього, в ході аналізу стану вивчення зазначеної проблеми встановлено, що механістичні погляди не належать якій-небудь одній країні чи науковій школі, а від самого початку формуються як сплав досягнень загальнолюдського розуму.

Невирімені питання. Незважаючи на велику кількість концепцій і теоретико-методологічних підходів щодо обгрунтування механістичного менеджменту, а також ту важливу роль, яку вони відіграли в утвердженні індустріалізму, слід зазначити, що всі вони досить розрізнені й трактуються переважно у відриві або в протиставленні до гуманістичної складової та виключно з позицій економічної ефективності. Поза увагою вчених, які працювали чи продовжують працювати в цьому напрямі, залишаються культурно-історичні аспекти механістичного менеджменту, його ключові передумови виникнення, системне бачення і перспективи подальшого розвитку. Невирішеність цих питань і важливість їх вивчення й обумовлює необхідність нашого дослідження.

\section{2. Мета і методи дослідження Purpose and methods of research}

Мета статті полягає у здійсненні теоретико-історичного аналізу культури механістичного менеджменту, виявленні базових детермінант генезису цієї культури управління та формування основних напрямів іiі розвитку в умовах індустріалізму. Вивчення цих питань дає можливість суттєво розширити уявлення про проблемне поле теорії й історії світової культури, включивши у нього раніше практично не досліджувані в історикокультурологічному контексті ідеї механістичного менеджменту.

Методологічною основою дослідження є діалектичний принцип пізнання, системний, цивілізаційний і культурологічний підходи до вивчення суспільних явищ і процесів, фундаментальні положення теорії та історії культури. Грунтуючись на цьому, культура механістичного менеджменту вивчається насамперед із точки зору загальних законів розвитку природи, суспільства і мислення. Об'єкт дослідження розглядається як система взаємодіючих елементів, що перебуває у постійному русі, розвитку й пристосуванні до мінливих умов, кардинальні зміни яких відбуваються 
у точках біфуркації цивілізації. Особливий ракурс дослідження проблеми механістичного менеджменту задає культурологічний підхід, який акцентує увагу на ролі цінностей і архетипів свідомості, трансформація яких багато в чому визначається тим чи іншим типом цивілізаційного розвитку людства.

Для вирішення окремих завдань використано культурно-історичний, типологічний, системно-структурний і функціональний методи, а також комплекс загальнонаукових методів пізнання, які дозволили усебічно дослідити різні грані явища механістичного менеджменту. Так, зокрема: культурно-історичний метод дає змогу вивчити процеси виникнення, формування і розвитку культури управління у хронологічній послідовності, завдяки чому досягається поглиблене розуміння суті проблеми; типологічний - допомагає вирішити завдання виявлення й аналізу соціокультурних типів механістичного менеджменту; системно-структурний i функціональний методи дозволять виявити функціонально-структурні зв'язки і закономірності в системі культури механістичного менеджменту.

Інформаційною базою дослідження послужили наукові праці провідних вітчизняних і зарубіжних вчених, найзначиміші наукові теорії 3 приводу пояснення культури механістичного менеджменту як об'єкту дослідження. Хронологічні межі дослідження охоплюють в основному індустріальний цикл розвитку цивілізації, а територіальні - визначаються здебільшого історичними теренами західного суспільства, в якому зароджувалися механістичні ідеї та звідкіля вони транслювалися на весь світ.

\section{3. Результати дослідження Research results}

Однією із найважливіших характеристик Людини, яка відрізняє іiі від тварини, є те, що вона у своїх діях спирається на розум, систему знань та їх оцінку. При цьому важливу роль, разом із Релігією, відіграє Наука, яка допомагає людині уявити навколишній світ, тобто побачити думками те, що називають Всесвітом і знайти своє місце в космічній $\mathrm{i}$ природній ієрархії. Проте в цій роботі нас цікавитиме історія науки не взагалі, а тільки та їі складова, яка виникла внаслідок пізньосередньовічної біфуркації цивілізації наприкінці «довгого» XVI ст., тобто наука Нового часу, або, іншими словами, Європейська наука, що стала базисом тієї культури, на якій грунтується індустріальне суспільство.

Важливо підкреслити, що на Заході саме з цього моменту наука Нового часу по суті стала поступово заміняти і відтісняти Церкву як вищий, єдиний авторитет, який легітимізував й освячував суспільний лад. Таким чином, нова наука стала інструментом панування. Згадаймо знаменитий афоризм англійського філософа Френсіса Бекона, що прозвучав на зорі індустріалізму (поч. XVII ст.): «Знання само по собі є силою...» (Бэкон, 1978, с. 12), який означає, що владою (силою) в такому суспільстві 
володіють ті, хто має знання. При цьому до науки починають звертатися, як у давні часи зверталися до жерців.

У західних країнах, де відбулися буржуазні революції, вчені зробили вагомий внесок у наукове обгрунтування нового ладу. Підставою для цього стали нові уявлення про навколишній світ, які сьогодні називають механістичною картиною світу, що пов'язується з іменами Г. Галілея, Й. Кеплера й особливо І. Ньютона. Світ у цій картині побудований на єдиному фундаменті - законах ньютонівської механіки, а всі причиннонаслідкові зв'язки на лапласівському детермінізмі, згідно з яким вважається, що якщо відомі початкові дані системи, то можна точно передбачити їі майбутнє, оскільки зв’язки - однозначні. Основу ж механістичної картини світу становить ідея атомізму, відповідно до якої матерія складається 3 неділимих частин - атомів, які перебувають у безперервному русі. Розвиваючи цю ідею, англійський філософ Томас Гоббс (1651р.) переносить їі в соціум і характеризує людину як егоїстичний та жадібний атом, що веде «війну всіх проти всіх» (2000, с. 156). Англійський фізик Ісаак Ньютон (1687 р.) і його послідовники з нової картини світу виводять тезу про природність конституції країни, яка повинна обмежити владу монарха, «адже Сонце підкоряється закону гравітації» $(1989$, с. 506).

Механіцизм і уявлення будь-якої реальності як машини, що випливає з ньютонівської картини світу, справляє дуже великий вплив на розуміння процесів управління в індустріальному суспільстві. Німецький філософ і математик Готфрід Лейбніц (1686 р.) писав: «Процеси в тілі людини й кожної живої істоти є такими ж механічними, як і процеси в годиннику» (Лейбниц, 1983, с. 93). Коли людину переконали, що вона - машина i водночас частинка іншої величезної машини, це дозволило перетворити іï на керований «гвинтик» індустріального суспільства. Світ, що був для людини традиційного суспільства Храмом, став великою Фабрикою.

Наука Нового часу зруйнувала цей Храм, представивши людині світ у вигляді Машини, яку можна описати мовою математики. Внаслідок цього людина опинилася за межами світу і була протиставлена йому як підкорювач. Із цього моменту моральні цінності залишилися у віданні релігії, а наука стала орієнтуватися тільки на об'єктивну істину. Це було зовсім новим у культурі. До цього акт пізнання був пов'язаний із релігією він творився в ім'я Добра, як крок до розуміння задуму Творця.

Слід зауважити, що в західній культурі перехід до уявлення світу як машини злився з Реформацією. Для пізнання світу, протиставленого людині, наука Нового часу запропонувала метод, що включає раціональне теоретизування, спостереження і експеримент. I світом, перед яким немає благоговіння, управляти стає набагато «легше».

Російський філософ Піама Гайденко пише: «Руйнується феодальна суспільна структура, індивід звільняється від зв’язків і обмежень, які раніше визначали його спосіб життя. Відбувається відділення виробника 
від засобів виробництва, розширюються ринкові відносини. На перше місце виступає приватний капітал, тобто індивід поводиться як окремий атом, а 3 хаотичного руху атомів складається рівнодіюча тенденція розвитку суспільства» (2003, с. 314). І отже, той індивідуалізм, на якому засновується вільне підприємництво, не міг виникнути без відчуття людиною себе як вільного атома людства. Інакше був би нестерпний розрив із громадами, в яких існувала людина традиційного суспільства - 3 патріархальною сім'єю, селом, церквою. Атомізм як наче природний порядок надав законність звільнення від феодальних структур і заклав філософську основу представницької демократії (одна людина - один голос).

Томас Гоббс у своїй книзі «Левіафан» (1651р.) представляє людину самотньою у ворожому оточенні, де ії визнання вимірюється владою над іншими. Співжиття індивідів визначається їх стартовою рівністю. Однак ця рівність відмінна від узаконеної в канонічному християнстві та традиційному суспільстві, в якому всі люди рівні за великим рахунком, бо створені за образом і подобою Бога. В індустріальному ж суспільстві рівними $€$ ті, хто у змозі завдати один одному однакові «удари», збитки у взаємоборотьбі. Рівність індивідів передбачає не любов і солідарність, а безперервну війну всіх проти всіх: «хоча блага цього життя можуть бути збільшені завдяки взаємодопомозі, вони досягаються набагато успішніше, пригнічуючи інших, ніж об'єднуючись із ними» (Гоббс, 2000, с. 85). Такі підвалини індустріального суспільства легітимуються природним правом, в якому немає місця для моральних норм. I за відсутності контролю ця взаємоборотьба означала б самознищення. Тому порядок у такому соціумі встановлюється на основі договору між «воюючими сторонами». Тобто, політична влада отримує легітимацію не «зверху», як ієрархія, освячена Божественним Одкровенням, а «знизу», від сукупності вільних індивідів.

Важливу роль в обгрунтуванні нового суспільного ладу й культури механістичного менеджменту зіграла не тільки ньютонівська картина світу, а й методологія пізнання. Наука Нового часу перебудовувала мислення на раціональну основу, що стало засобом звільнення людини від норм, зафіксованих у традиціях. Французький філософ-раціоналіст Рене Декарт у своїй праці «Роздуми про метод» (1637 р.) зазначає: «Ніколи не приймати за істинне нічого, що я не пізнав би таким з очевидністю... включати в свої судження тільки те, що видається моєму розумові настільки ясно й настільки чітко, що не дає мені жодного приводу піддавати це сумніву» (2017, с. 109). Але слід зауважити, що застосування чисто наукового підходу до цілісного осмислення суспільних проблем насправді не завжди є наукою, інколи це більше схоже на науковість - необгрунтовану операцію, імітацію науки. На обмеженість компетенції науки Нового часу вказували багато вчених. Родоначальник німецької класичної філософії Іммануїл Кант у книзі «Критика чистого розуму» (1781 р.) пише: «є щось там, за тими межами, куди наука не може проникнути» (2016, с. 62). Один із творців 
квантової механіки, лауреат Нобелівської премії Вернер Гейзенберг (1970р.) додає, що «не слід допускати виродження усіх інших пізнавальних органів за рахунок розвитку одного раціонального аналізу, що треба осягати дійсність усіма дарованими нам органами й сподіватися на те, що у такому випадку дійсність, яка нам відкрилася, відобразить сутнісне» (2001, с. 183). Це, на наш погляд, треба особливо пам'ятати при застосуванні наукового методу до пізнання об' єктів управління й розуміти, що методи механістичного менеджменту багато в чому обмежені.

Потужний вплив на становлення індустріалізму, формування його господарської моделі та культури управління здійснила політекономія, яку спочатку було представлено як природничу науку, повністю вільну від моральних обмежень і цінностей. I якщо політекономію розглядати через призму арістотелівського вчення, то це наука про хрематистику вид діяльності, який спрямований на накопичення багатства, у противагу іншому виду діяльності - економії, націленої на задоволення необхідних (вітальних) потреб людини.

Духовною основою прийняття західним суспільством хрематистики (ринкової економіки та бізнесу) стала протестантська етика. 3 цього приводу німецький соціолог Макс Вебер у своїй книзі «Протестантська етика i дух капіталізму» (1905 р.) писав: «Вище благо цієї етики насамперед у наживі, в усе більшій наживі при повній відмові від насолоди, дарованої грішми... ця нажива до такої міри мислиться як самоціль, що стає чимось трансцендентним і навіть просто ірраціональним щодо “щастя" або “користі” окремої людини» (2016, с. 79).

Нова господарська модель - ринкова економіка і бізнес виникли як глибока мутація в дуже специфічній культурі. Вони появилися тоді, коли на товар перетворилися речі, які у традиційному суспільстві ніяк не могли вважатися товаром, - гроші, земля та робоча сила. Це був глибинний переворот у свідомості тогочасної людини.

Перетворення людини на вільний «атом» змінювало ідею держави, яка раніше була патерналістською. Ватажок Реформації Мартін Лютер легітимізував класову державу, в якій представником Бога стає не монарх, а клас багатих. Засновник класичної політекономії Адам Cміт у своїй праці «Про природу і причини багатства народів» (1776 р.) визначив головну роль держави в охороні приватної власності від тих, хто власності не має (Смит, 2016, с. 833). I саме індустріалізм породив той тип держави, який Гоббс охарактеризував як Левіафан - наділений міццю страж, що здатний увести в законні рамки цю війну всіх проти всіх (конкуренцію).

Базуючись на механістичній картині світоустрою, економіка була представлена машиною, що діє за природними законами, тільки замість руху мас був рух товарів, грошей і робочої сили. Абстракція людини економічної була абсолютно аналогічною абстракції матеріальної точки в кінематиці. 3 механіки було перенесено принцип рівноваги. І навіть слідом 
за Ньютоном була введена деяка потойбічна сила, яка мала приводити економіку в рівновагу - це «невидима рука ринку» (у механіці «невидима рука» використовувалася для пояснення руху під впливом гравітації).

Народження індустріального суспільства й механістичної культури менеджменту тісно пов'язується також із успіхами в розвитку техніки Нового часу. До найбільш значущих досягнень цього періоду відносяться наступні науково-технічні відкриття (Федюкин, 2007):

1. Створення парової машини (теплодвигуна зовнішнього згоряння, Д. Папен, Франція, кін. XVII ст.), а в подальшому - пароплава, паровоза та поява першої фабрики (Кромфорд, Англія, 1771 р.). Цей історичний період іменують віком пари. Він, в основному, охоплює XVIII-XIX ст., а в деяких галузях людської діяльності й період до серед. XX ст.

2. Відкриття явища електромагнітної індукції (М. Фарадей, Англія, 1831 р.) і створення технологій отримання, передачі й перетворення електроенергії на інші види енергії (механічну, світлову, теплову):

- винайдення першої динамо-машини (В. Сіменс, Німеччина, 1867 р.), генератора (Т. Едісон, США) і турбогенератора (Г. Лаваль, Швеція, 1883 р.);

- винахід способу транспортування електроенергії на великі відстані за допомогою спеціальних ліній електропередачі (М. Депре, Франція, 1881 р.);

- відкриття системи трифазного змінного струму і побудова відповідних генератора, трансформатора й електродвигуна (М. Доліво-Добровольський, Росія, Німеччина, 1889 р.);

- винахід різних конструкцій електролампи (в Росії - О. Лодигін, 1873 р. і П. Яблочков, 1875 р.; в США - Т. Едісон, 1879 р.);

- побудова першої гідроелектростанції (р. Ніагара, США, кін. ХІХ ст.).

У результаті цих винаходів почалася електрифікація промисловості, транспорту, міської інфраструктури, домоволодінь.

3. Винахід теплових двигунів внутрішнього згоряння: бензинового (Н. Отто, 1877 р.) і нафтового (Р. Дизель, 1893 р., Німеччина) та поява автомобіля (1885 р.), тепловоза (1891р.) й аероплана (1903р.).

4. Виникнення нових видів зв’язку: телефону (А. Белл, США, 1876 р.) і радіоприймача (О. Попов, Росія, 1895 р.).

5. Винайдення нових способів виробництва сталі в конвертері під сильним дуттям (Г. Бессемер, Англія, 1856 р.) і у спеціальній плавильній печі (П. Мартен, Франція, 1864 р.), у результаті чого світова виплавка сталі зросла у понад 200 разів.

6. Отримання целулоїду (Д. Гаят, США, 1869 р.), на основі якого було запропоновано виготовлення штучного волокна, розроблені синтетичні способи отримання органічних сполук для виробництва барвників, лікарських, парфумерних та інших продуктів.

Впровадження машин дозволяло здійснювати стрімке зростання продуктивності праці й водночас посилювало поділ праці між робітниками та підприємствами, що вимагало відповідних способів управління. 
На початку XIX ст. стали з'являтися праці, присвячені вивченню нових тенденцій у розвитку машинного виробництва. Такі праці з'являлися у країнах Європи і США. Однак найцікавішими були роботи англійських вчених, що було пов'язано з тим, що Великобританія першою вступила на шлях індустріалізації. Наприкінці XIX ст., після того, як лідерство перейшло до США, концептуальними для становлення культури механістичного менеджменту стали праці американських вчених і практиків.

Фундаментальне значення для становлення культури механістичного менеджменту мали ідеї англійського математика Чарльза Беббіджа про спеціалізацію та поділ праці, висвітлені у його книзі «Економіка машин і виробництв» (1832р.), що дозволяє зрозуміти природу машинного виробництва. Ч. Беббідж виділив такі переваги спеціалізації: вона дозволяє скорочувати час, необхідний для оволодіння професією; зменшує витрати матеріалів; виключає час, необхідний на перехід від однієї роботи до іншої; дає можливість домогтися високого рівня кваліфікації; стимулює працезаощадні інновації; забезпечує краще поєднання людини та іiі завдання (Babbage, 2009, p. 301-306). Отже, спеціалізація сприяє економії робочого часу, підвищує рівень вмілості працівників, знижує загальні витрати і в результаті веде до зростання продуктивності та прибутку фабрики.

Особливу роль в утвердженні механістичної культури управління відіграли дослідження шотландського вченого Ендрю Юра, викладені в книзі «Філософія виробництва» (1835р.). Ключовими поняттями, якими оперує вчений, $\epsilon$ «філософія виробництва» та «філософія фабрики», які протиставляються поняттю «філософія витончених мистецтв». Е. Юр був активним прихильником фабричного виробництва й підкреслював його високу продуктивність та набагато кращі умови праці, ніж невеликий цех чи майстерня. До того ж у фабричній системі він бачив велике майбутне і мріяв побудувати суспільство відповідно до структури фабрики (Ure, 1835).

Значний внесок у теорію культури механістичного менеджменту здійснив польський філософ Броніслав Трентовський. Найвідоміший його твір - «Ставлення філософії до кібернетики як мистецтва управління народом», в якому об'єкт і суб'єкт управління позначено термінами «кіберно» та «кібернет». Відповідно до цього, кібернетика визначається як мистецтво управління людьми. Водночас вчений зауважує, що в міру розвитку суспільства одного мистецтва управління замало й воно чимраз більшою мірою повинно набувати рис наукового дослідження, а кібернет рис вченого (Trentowski, 1843). Б. Трентовський також розвивав ідеї системності й ситуаційності менеджменту. На його думку, ефективний менеджмент має враховувати конкретну ситуацію та всі найважливіші зовнішні і внутрішні чинники, що впливають на об’єкт управління.

Наприкінці XIX ст. у США почала розвиватися так звана американська система виробництва, в якій роль менеджерів правомірно належала інженерам. Однак існував низький рівень виробничої культури, й робота 
інженерів майже цілком грунтувалася на досвіді та інтуїції, а до тих, хто хотіли внести у свою роботу елементи наукового підходу, ставилися 3 недовірою. Повагою користувався скоріше той інженер, який міг, наприклад, палицею накреслити на підлозі фабрики контури потрібної йому деталі й на основі такого креслення організувати її виготовлення.

Початком розвитку автономної теорії механістичного менеджменту слід вважати 1886 р., коли на зборах Американського товариства інженерівмеханіків (ASME) була представлена доповідь Генрі Тауна «Інженер як економіст», яка багато в чому визначила напрямок подальшої еволюції культури менеджменту. У своїй доповіді Г. Таун відзначав, що наявний управлінський досвід не став предметом теоретичного узагальнення й доводив, що менеджмент має бути перетворений на особливу науку. Він вважав менеджмент мистецтвом, подібним технічному конструюванню, але принципово новим у нього був акцент на економічну складову в діяльності інженерів, які до цього цікавилися лише технічними питаннями (Дункан, 1996, с. 143). Вважається, що саме цей виступ Г. Тауна надихнув Ф. Тейлора на розробку теорії механістичного менеджменту.

Взагалі в культурі механістичного менеджменту можна виділити три самостійних напрями: культура наукової організації праці й управління, адміністративна культура та бюрократична культура. Їх об'єднує спільний підхід до розгляду процесів управління, а саме механіцизм.

Творцем теорії наукової організації праці та управління вважається американський інженер Фредерік Тейлор. Хоча сам Тейлор засновником цієї теорії вважав Тауна. Однак у подальшому саме з ім'ям Тейлора стали пов'язувати виникнення ідей наукової організації праці й управління. Це сталося завдяки тому, що саме він обгрунтував їх на великому обсязі емпіричного матеріалу та доклав неабиякі здібності для їх поширення.

Свою першу доповідь на засіданні ASME «Система відрядної оплати» Ф. Тейлор зробив у 1895 р. Вона була присвячена не тільки розгляду питань заробітної плати, а й проблемам організації виробництва в цілому. Тейлор вважав раціональну систему оплати праці одним із найважливіших елементів управління виробництвом. Він писав, що головна його мета - довести, що висока заробітна плата й доволі невеликі витрати на неї заводу є основою досконалого управління. На його думку, «система оплати повинна розбудити самолюбство й інтерес... Люди не будуть працювати напружено, якщо вони не впевнені в дуже гарному заробітку» (Taylor, 1896, p. 4-5).

Розробку своєї системи Ф. Тейлор продовжив у роботі «Управління фабрикою» (1903р.). Він зауважував, що основою найкращого управління $\epsilon$ поєднання високих ставок і дешевизни робочої сили, а можливість цього «базується на величезній різниці між кількістю роботи, яку може виконати першокласний робітник при сприятливих умовах, і тим, що фактично виконується рядовим робітником» (Тейлор, 1992, с. 35). Спираючись на численні дослідження, Тейлор встановив для максимальної продуктивності 
певні рівні підвищення ставок. Водночас він вважав, що переплачувати працівникам так само шкідливо, як і не доплачувати.

При розробленні своєї системи Тейлор заперечував колективні форми винагороди й наполягав на індивідуалізації оплати праці працівника, оскільки в цьому випадку стимулюється його особисте самолюбство, $\mathrm{i}$ робота стає продуктивнішою. Встановлення ставок, згідно з системою, обов'язково має відбуватися на основі точно вивірених стандартів трудових операцій і визначення конкретних уроків працівникам. Підкреслювалося, що розпорядження повинні даватися робітникам й у всіх подробицях. Своєю чергою, працівники повинні щодня надавати письмові рапорти.

Ф. Тейлором вперше було представлено систему функціонального управління і вказано на неефективність поширеного лінійного адміністрування. Зазначалося, що важко знайти людину, яка поєднувала б у собі різні знання і вміння, необхідні для виконання всіх обов'язків керівника. Тому необхідно замінити одного керівника кількома функціональними начальниками, кожному з яких потрібно володіти лише невеликим числом необхідних якостей (Тейлор, 1992, с. 57). Також Тейлор вперше запропонував створити на підприємстві плановий відділ та сформулював правила успішного керівництва: прагнути до збереження добрих відносин із робітниками; заохочувати особисте самолюбство працівника або шляхом підвищення окладу, або шляхом підвищення в посаді; вести розмови з робітниками у тоні, відповідному до їхнього рівня; щодо різних людей застосовувати неоднакові заходи впливу (Там само, с. 124-136).

У 1911 р. Ф. Тейлор опублікував книгу «Принципи наукового управління», у якій сформулював основні принципи управління:

1) адміністрація виробляє науковий фундамент, що заміняє старі грубо-практичні методи, для кожної окремої дії в усіх різновидах праці;

2) адміністрація, на основі науково встановлених ознак, ретельно відбирає робітників, а потім їх тренує, навчає і розвиває;

3) адміністрація співпрацює з робітниками для досягнення відповідності виробництва науковим принципам;

4) встановлюється майже рівномірний розподіл праці й відповідальності між адміністрацією і робітниками (Taylor, 1997, p. 101-105).

Комбінація ініціативи робітників у поєднанні з новими типами функцій, здійснюваних адміністрацією, робить наукову організацію такою, що значно перевершує за продуктивністю всі старі системи.

Як складові культури наукового управління Ф. Тейлор розглядав: нормування та облік робочого часу; систему функціональних майстрів; стандартизацію знарядь праці; введення планового бюро й інструкційних карток для робітників; ідею уроку в поєднанні з великими преміями за успішне його виконання; диференціальну оплату праці; введення системи розпорядку ходу робіт; систему калькуляції собівартості і т. д. 
Система Тейлора набула широкого поширення у перші десятиліття XX ст. В історію культури менеджменту Ф. Тейлор увійшов як творець індустріальної управлінської науки. Він перший довів, що управляти треба науково, спираючись на експерименти, аналіз й узагальнення.

На думку гуру теорії менеджменту Пітера Друкера, розмови щодо поліпшення робіт велися протягом тисячоліть, але мало хто до Тейлора справді використовував комплексний підхід до організації роботи. Науковий менеджмент «носить новаторський характер... без нього справжнє вивчення людини у процесі роботи було б неможливим» (2007, с. 283).

Отже, теорія культури наукової організації праці та управління, запропонована Тейлором, справила великий вплив на розвиток управління в усьому світі. Рух «за наукове управління» вже у другому десятилітті $\mathrm{XX}$ ст. набув міжнародного розмаху, охопивши промислово розвинені країни та країни, що розвиваються з різними типами економічних систем.

Найвідомішими продовжувачами ідей Тейлора стали: у США Г. Гант, Ф. і Л. Гілблети, Г. Емерсон, Г. Форд; у Франції - А. Шательє, у Великобританії - Л. Урвік, у Німеччині - В. Ратенау, в Бельгії Е. Ландауер, у Польщі - К. Адамецкій, в Росії - О. Гастєв, в Україні Ф. Дунаєвський та інші вчені й практики управління.

Американський інженер Генрі Гант займався пошуком точних методів аналізу управлінських проблем і вбачав одну з причин неефективності в тому, що завдання й окремі норми визначалися роботою у минулому або чиєюсь суб'єктивною думкою про те, що могло бути зроблено. Однак наукове управління може вирішити завдання збільшення продуктивності праці тільки за умови точного знання. На його думку, менеджери повинні проводити науковий аналіз кожного елементу виробничого процесу. Для знаходження найефективнішої форми комплексної операції необхідно спочатку розділити їі на більш прості складові й вивчити кожну з них, а потім шляхом підсумовування частин відновити весь комплекс операції.

На відміну від Тейлора, для якого всі фактори виробництва були рівнозначними, Гант підкреслював пріоритет людського фактора. На його думку, найважливішу роль у процесі раціоналізації виробництва відіграє персонал, яким потрібно не управляти, а розвивати. У своїй статті «Навчання робітників навичкам промислової праці та співпраці» (1908р.) він вказує на необхідність розвитку «звичок виробництва»: працьовитості, чесності, кооперації, максимального використання працівником своїх здібностей і постійне прагнення до зростання кваліфікації (Gantt, 2016, p. 78). Результатом цього має стати задоволення працею, зниження витрат, зростання продуктивності праці та її оплати.

Важливим внеском Ганта в культуру індустріального менеджменту $\epsilon$ створення графічної інтерпретації управління. Він вважається творцем оперативного й календарного планування. Система планових графіків отримала назву діаграм Ганта. Принципи, на яких базується цей метод, 
такі: будь-яка робота може бути оцінена за часом, який необхідний для іiї виконання; простір, яким показується на схемі час, відповідає обсягу робіт, що повинен бути проведений у цей час (Gantt, 2014, p. 59). Такий підхід робить можливим графічне уявлення будь-якого виду роботи.

Г. Гант є одним із засновників концепції соціальної відповідальності бізнесу. Ця концепція знайшла відображення у роботі «Організація праці» (1919 р.). Він вважав, що компанії мають зобов'язання перед суспільством і повинні бути відповідальними. Їх основною метою має бути не отримання прибутку, а служіння суспільству (Gantt, 2017, p. 81).

Американське подружжя Френк $i$ Ліліана Гілбрети основну увагу в своїй діяльності приділяли проблемам раціоналізації праці робітників, питанням вивчення фізичних рухів у виробничому процесі, дослідженню втоми та ії впливу на здоров'я і продуктивність праці.

Ф. Гілбрет займався пошуком шляхів підвищення продуктивності праці без докладання великих фізичних зусиль. Почавши свою діяльність муляром, він сконцентрував увагу на вивченні рухів. На основі вивчення різних систем руху, аналізу інструментів і робочих місць Гілбрет запропонував новий спосіб кладки цегли, при якому муляр для кладки однієї цеглини замість 18 рухів став виконувати тільки 5. При цьому акцент було зроблено на економію зусиль, а не на швидкість.

У своїй праці «Вивчення рухів» (1911р.) Ф. Гілбрет розглядав уже не процес кладки, а роботу взагалі. Він звернув увагу на те, що втрата природних ресурсів жахлива, але вона ніщо порівняно з втратами продуктивності праці, які пов'язані з надмірними трудовими рухами. На його думку, на основі аналізу рухів і розробки методів їх вдосконалення можлива величезна економія праці в будь-якій сфері людської діяльності.

Гілбрет розвинув ідею Тейлора про необхідність розробки нормативів витрат часу на кожен елемент трудових операцій. Він розчленував абстрактний трудовий процес на взаємозамінні прийоми, з комбінацій яких у їх різних поєднаннях і послідовностях повинна складатися будь-яка операція.

За допомогою кінокамери і мікрохронометра Гілбрет виявив й описав 17 базових рухів, які назвав терблігами. На його думку, якщо розробити норми часу для кожного з них, то легко можна буде розрахувати норму часу для будь-якої операції, оскільки вона являє собою комбінацію терблігів (Gilbreth, 2013, p. 105). На основі цього велике поширення в культурі управління отримали технологічні карти, в яких відображалася послідовність усіх здійснених із деталями операцій.

Досліджуючи чинники, що впливають на продуктивність праці, Ф. Гілбрет виділив їх три групи: 1) змінні в робітнику: сила, переконання, прагнення до заробітку, досвід, стомлюваність, звички, здоров'я, ріст, майстерність, темперамент; 2) змінні в умовах: одяг, опалення, охолодження, вентиляція, освітлення, винагороди й покарання, знаряддя; 3) змінні в 
русі: прискорення, автоматичність, комбінація з іншими рухами, долаючі моменти й інерція, швидкість (Gilbreth \& Gilbreth, 2012, p. 96-99).

На відміну від багатьох своїх колег, Ф. і Л. Гілбрети значну увагу приділяли проблемі втоми. У роботі «Дослідження втоми» (1916 р.) вони писали: «Мета життя - щастя, і не важливо, хто як його розуміє. Усунення втоми, що виникає з бажання зберегти людське життя, усунувши перевантаження, має збільшити кількість чудових миттєвостей (навіть якщо у нього $є$ й інші цілі)» (Gilbreth \& Gilbreth, 2010, p. 129). Було виділено два види втоми: 1) надлишкова - наслідок дій, які не є необхідними, що можна мінімізувати шляхом раціональної організації робочого місця; 2) необхідна виникає при виконанні потрібних дій, яку можна зменшити завдяки передовим методам організації виробництва та необхідним перервам.

Американець Гаррінгтон Емерсон вважається першим інженером з ефективності. На його думку, ефективність виробництва не $\epsilon$ функцією надлишку або нестачі ресурсів: навіть маючи їх у достатній кількості, країна може втрачати свої переваги через нераціональне їх використання. Тільки правильна організація може забезпечити ефективне застосування машин, матеріалів і людських зусиль, зниження витрат виробництва.

У своїй роботі «Дванадцять принципів продуктивності» (1912р.) Г. Емерсон представив загальну концепцію ефективності використання праці та сформулював принципи правильної іiі організації. Він підкреслював, що будь-яке підприємство може працювати продуктивно тільки в тому випадку, якщо $є$ належно побудована організація, на чолі якої стоїть керівник, який застосовує такі принципи: 1) точно поставлені цілі; 2) здоровий глузд; 3) компетентна консультація; 4) дисципліна; 5) справедливе ставлення до персоналу; 6) швидкий, надійний, повний, точний і постійний облік; 7) диспетчеризація; 8) норми й розклади; 9) нормалізація умов; 10) нормування операцій; 11) писані інструкції; 12) винагорода за продуктивність (Emerson, 1912).

Для того щоб люди працювали добре, у них повинні бути ідеали. Щоб робота давала максимальні результати й супроводжувалася радісним піднесенням, необхідне дотримання трьох умов: вона повинна приносити задоволення й бути не каторгою, а грою; робота повинна вимагати певних результатів у певний термін, не повинна бути невизначеною; необхідна професійна невимушеність.

На поч. XX ст. найпоширенішими були лінійна, функціональна й штабна структури організації. Емерсон вважав, що підвищення ефективності управління можливо за рахунок доповнення лінійного принципу побудови структури штабним принципом. При цьому для злагодженої роботи лінійних і штабних підрозділів необхідна чітка координація їх взаємовідносин. Основне завдання штабних підрозділів полягає в тому, щоб «кожен член лінійного підрозділу міг у будь-який час отримати вигоди зі штабних знань» (Emerson, 1912, p. 334). Емерсон зауважував, що ієрар- 
хічні щаблі управління створюються для поліпшення обслуговування нижніх ланок, а не для полегшення існування вищих.

Винахідник, піонер автомобілебудування Генрі Форд не тільки на практиці реалізував багато принципів теорії Ф. Тейлора, а й значно модернізував вихідні постулати культури наукового управління. Його підхід отримав назву «фордизм».

Г. Форд розвинув концепцію соціальної відповідальності бізнесу, запропоновану Гантом. На думку Форда, підприємницька діяльність повинна служити суспільству. Розглядаючи особливості бізнесу, він виділив його недоліки. Перший - надмірна увага до фінансів і практично повна зневага до принципу служіння. Другим недоліком є небажання удосконалювати методи виробництва, якщо воно приносить прибуток. Третім байдужість до того, чи буде покупець задоволений продуктом. Він намагався продемонструвати, що основа будь-якого бізнесу - служіння людям.

Г. Форд вважав, що раціональне використання ресурсів, організація поточно-масового виробництва приводять до збільшення продуктивності й створення нових робочих місць, здешевлюють товари, роблять життя комфортнішим і тим самим ведуть до процвітання будь-якої країни. Завдання підприємства - виробляти для споживання, а не для наживи або спекуляції. У роботі «Моє життя, мої досягнення» (1922 р.) Форд писав, що мета його виробництва полягає в тому, щоб «виробляти з мінімальними витратами як матеріалу, так і людської сили, реалізовувати за мінімальними цінами, намагаючись виграти за рахунок обсягу продажів» $(2014$, с. 87$)$. Удосконалення моделі автомобіля, технології його виготовлення, впровадження наукової організації праці та конвеєрного складання, створення фордівської системи управління дозволили за 10 років скоротити ціну автомобіля 3 950 до 335 дол. Оскільки середньомісячна зарплата становила 120 дол., працівник компанії Форда міг купити автомобіль приблизно за 3 місяці.

На відміну від Тейлора, який займався раціоналізацією переважно ручної праці, Форд замінив ручну працю машинами й зосередив свою увагу на раціоналізації механізованої праці. Одним із перших він став застосовувати потокові методи організації виробництва й використовувати конвеєрне складання. Конвеєризація дозволила швидко підвищити продуктивність праці без безпосередньої участі майстра, який постійно підганяв робітника. Підлаштовуючись до швидкості руху конвеєра, робітник сам автоматично починав працювати швидше.

Так само, як і Тейлор, Форд велике значення надавав питанням стандартизації виробництва й оперативному плануванню. В обов'язки тих, хто складав плани, входив також контроль за тим, щоб усі працювали злагоджено на спільну мету. Він виступав категорично проти бюрократизації. На всіх підприємствах були відсутні адміністративна структура, жорсткі обов'язки відповідно до посад, титули й звання. Звільнення від жорсткої субординації приводило до мінімізації службової тяганини й зловживань 
службовим становищем. Будь-який робітник міг звернутися до будьякого вищестоящого начальника. На перше місце реформатор поставив особисту відповідальність. Він підкреслював, що «робота і тільки робота, контролює нас» (Форд, 2014, с. 321).

До числа цікавих проектів Г. Форда можна віднести його соціальну програму, реалізовану в 1914-1920 рр., основні положення якої можна звести до наступного: скорочення тривалості робочого дня до 8 год.; навчання працівників на робочому місці; революція в оплаті праці, яка полягала у виплаті робітникам надбавки з прибутку; соціокультурне управління за межами підприємства; надання іммігрантам рівних можливостей влаштування на роботу й отримання надбавки; відсутність дискримінації при прийомі на роботу; обмеження прийому на роботу дружин робітників; заснування добровільних позиково-ощадних кас для працівників.

Таким чином, для Г. Форда, як і для культури наукового управління в цілому, характерний механістичний підхід, при якому на менеджмент організації дивилися як на управління машиною.

Засновником адміністративного напряму в культурі механістичного менеджменту, який виник на поч. XX ст. в Європі, вважається французький інженер Анрі Файоль. Його погляди викладені у книзі «Загальне і промислове управління» (1916 р.) й базуються на таких методологічних підходах (Файоль, 1992):

1) організація являє собою цілісний соціальний організм, подібний до живого, де людина схожа на клітину, а адміністрація - на нервову систему;

2) цей організм може бути організований по-різному: від найпростіших форм, коли керівник зосереджує у своїх руках управління і виконання, до великих структур, у яких керівник взагалі позбавлений виконавчих обов'язків;

3) процес організації - це створення структури підприємства відповідно до поставлених цілей, де для кожного компонента строго окреслено місце та функції, між частинами компанії відбувається гармонійна координація;

4) менеджер - це системний контролер, який задіяний у: плануванні, прийнятті рішень, їх коригуванні, виконанні; створенні впорядкованої структури; визначенні обов'язків, схем оплати праці так, щоб працівники належним чином їх виконували й отримували адекватну винагороду;

5) пошук принципів, які дозволяють побудувати формальну структуру організації і керувати нею раціональним чином, забезпечуючи передбачуваність ірраціональної сторони людської натури;

6) модель людини в адміністративній культурі менеджменту передбачає, що у процесі праці вона поводиться раціонально й діє так, як від неї вимагає формальний план, а мета полягає у максимізації заробітку;

7) в адміністративних справах немає нічого абсолютного, всі принципи є гнучкими, а мистецтво адміністрування полягає у правильному їх застосуванні з урахуванням певних обставин. 
На думку А. Файоля, яким би не було підприємство - малим або великим, - у ньому завжди зустрічається шість груп функцій: 1) технічні (виробництво); 2) комерційні (купівля, продаж); 3) фінансові (залучення коштів і розпорядження ними); 4) страхові (страхування, охорона майна й осіб); 5) облікові (бухгалтерія, калькуляція, облік, статистика); 6) адміністративні (передбачення, організація, розпорядництво, координування i контроль) (1992, с. 9-12), які перебувають у тісній залежності одна від одної. Наприклад, технічна функція не може здійснюватися без сировини, без можливості збуту, без капіталу, без страхових заходів та без передбачення.

Основну увагу Файоль приділяє розгляду шостої, адміністративної функції, оскільки, на його думку, жодна з п'яти попередніх не включає завдання вироблення програми роботи підприємства, підбору кадрів, координування зусиль, гармонізації дій. Він пише, що важливо не змішувати адміністративну функцію з управлінням. Управляти - означає забезпечувати дію шести істотних функцій. Адміністрування ж є лише однією із шести функцій. Отже, А. Файоль проводить розмежування понять «управління» і «адміністративна діяльність», останнє з яких має більш вузьке значення.

Кожній групі функцій відповідає спеціальна установка (технічна, комерційна, фінансова і т. д.), якою повинен володіти персонал, грунтуючись на сукупності певних якостей, які Файоль звів до шести груп: фізичні; розумові; моральні; загальний розвиток; спеціальні знання щодо виконання якоїсь однісї функції; досвід (1992, с. 12-13). У результаті багаторічних спостережень він дійшов таких висновків:

a) головною установкою робітника $\epsilon$ технічна; в міру просування за ієрархічними щаблями відносна важливість адміністративної установки зростає, у той час як важливість технічної убуває;

б) головною установкою керівника малого підприємства $\epsilon$ технічна; в міру переходу до більших підприємств зростає значення адміністративної й убуває значення технічної установок керівника.

Заключний висновок Файоля полягає в тому, що адміністративна установка виступає головною установкою для керівників вищих рівнів.

Таким чином, якщо функція адміністрування виконується належним чином, то очевидно так само добре іде справа й з іншими. Тому найперша умова, якій повинен задовольняти керівник, - бути гарним адміністратором. Друга умова полягає в тому, щоб він був компетентний у спеціальній технічній функції, характерній для певного підприємства.

Основу теорії адміністративної культури А. Файоля становлять принципи управління (1992, с. 15-48):

- поділ праці, метою якого є підвищення кількості та якості виробництва при витраті тих самих зусиль, а результатом - спеціалізація функцій та поділ влади; 
- влада як право віддавати розпорядження і сила, що змушує їм підкорятися; Файоль розрізняє авторитет влади, пов'язаний із займаною посадою, й особистий авторитет, заснований на розумі, досвіді і т. п.; особистий авторитет повинен бути необхідним доповненням до влади за посадою; влада немислима без відповідальності, тобто без санкції нагороди або покарання, що супроводжує їі дію;

- дисципліна, під якою мається на увазі покора, старанність, дієвість, манера тримати себе, зовнішні знаки поваги;

- єдність розпорядництва - означає, що працівникові може давати накази тільки один начальник; якщо це порушується, то наноситься шкода авторитету влади, підривається дисципліна, наступає хаос;

- єдність керівництва, що зводиться до єднання дій, координування сил і формування зусиль, спрямованих на виконання однієї програми;

- підпорядкування часткових інтересів загальним - означає, що інтереси працівника або групи працівників не повинні ставитися вище інтересів організації;

- винагорода персоналу, яка є оплатою виконаної роботи, повинна бути справедливою; пропонується комбінувати поденну, поурочну й поштучну форми заробітку в поєднанні із преміями, участю в прибутках, додаванням натурою, виплатами заслуг і нематеріальними стимулами;

- централізація як явище природного порядку, що полягає в тому, що як у живому, так і в соціальному організмі сприйняття сходяться в одному центрі - у мозку або в дирекції - звідки виходять накази, що приводять в рух весь організм; масштаби централізації або децентралізації - питання розумної міри;

- ієрархія - ряд керівних посад, починаючи з вищих і закінчуючи нижчими, колія, по якій проходять всі команди та звіти; однак рішення проблем шляхом звернення до цієї колії не завжди виявляється швидким, і тому для уникнення втрати часу пропонується використовувати делегування підлеглим прав і відповідальності зі здійснення комунікацій;

- порядок матеріальний і соціальний; формула матеріального порядку - певне місце для кожної справи й будь-яка річ на своєму місці; формула соціального порядку - певне місце для кожної особи й кожна особа на своєму місці;

- справедливість - результат поєднання доброзичливості з правосуддям; головним у поводженні з персоналом повинна бути вимога справедливості й рівності, не забуваючи про дисципліну;

- сталість складу персоналу, яка залежить від системи планування кадрів і застосовуваних методів управління; навіть краще мати посереднього працівника, ніж видатного, який збирається покинути організацію;

- ініціатива - можливість складання і реалізації плану, свобода пропозиції та іï здійснення, що є одним із найсильніших стимулів, який визначає поведінку працівників, забезпечує мотивацію і задоволеність роботою; 
можливість прояву ініціативи повинна бути надана всім за рахунок делегування повноважень;

- єднання персоналу, корпоративний дух, що є силою, яка забезпечує створення та підтримку в організації певної гармонії.

У запропонованих принципах немає нічого негнучкого й абсолютного. Автор підкреслював, що майже ніколи не доводиться застосовувати один i той самий принцип у тотожних умовах. Мистецтво адміністрування саме і полягає в тому, щоб правильно застосувати їх у різних і мінливих обставинах. Це важке мистецтво, яке потребує вдумливості, досвіду, рішучості та почуття міри.

Загалом, хоча виділені принципи носять розпорядчий характер, вони допускають гнучку інтерпретацію. А. Файоль писав: «без принципів ми у темряві, в хаосі; без досвіду й міри, навіть із найкращими принципами, ми теж у скрутному становищі. Принцип - це маяк, що допомагає орієнтуватися: служити він може тільки тим, хто знає шлях у порт» (1992, с. 49).

Файоль виходив із того, що дотримання універсальних принципів управління неминуче приведе до успіху. Запропоновані ним принципи на поч. XX ст. сприяли впорядкуванню управлінського процесу в багатьох західних компаніях. Вони залишаються корисними й досі.

Вагомим внеском А. Файоля в управлінську культуру є створення нового функціонального підходу, виділивши п'ять основних елементів адміністрування, які визначають сферу діяльності, компетенції та міру відповідальності менеджера (1992, с. 53-82):

1. Передбачення. За Файолем, передбачити - означає обчислювати майбутнє і підготовляти його. Передбачення майбутнього організації та визначення заходів, необхідних для переходу в цей новий стан, - найістотніший елемент і початковий пункт управління. Головним проявом i засобом передбачення служить програма дій (план), яка повинна грунтуватися на ресурсах, природі операцій та можливостях майбутнього, визначити які наперед дуже важко. На думку А. Файоля, план повинен відповідати вимогам єдності (загальний план має підтримуватися планами підрозділів), безперервності (одночасне використання короткострокового й довгострокового планування), гнучкості (можливість корегування і адаптації плану до змін) та точності. Акцент Файоля на необхідності планування був унікальним для свого часу. Відповідно до його концепції необхідне складання денних, тижневих, місячних, річних, п'яти- і десятирічних прогнозів, які повинні постійно корегуватися.

2. Організація. Організувати, за А. Файолем, означає забезпечити підприємство всім тим, що необхідне для його нормального функціонування: сировиною, обладнанням, грошима, персоналом. Файоль детально аналізував принципи побудови соціального організму підприємства, органи якого виконують шість істотних функцій. У малій фірмі вони можуть бути представлені одним службовцем; на великому підприємстві вони 
вкрай ускладнені, розділені й вимагають великої кількості працівників. Отже, на думку Файоля, форма, яку приймає підприємство, насамперед залежить від кількості співробітників.

3. Розпорядництво. Цей елемент управління з'являється після того, як організація сформована і її потрібно привести в дію. Метою розпорядництва $є$ залучення підлеглих у коло інтересів підприємства. А. Файоль вважає, що для цього керівник повинен пам'ятати наступні правила: добре знати своїх підлеглих і трудові угоди з ними; усувати нездатних; подавати гарний приклад; робити періодичні огляди підприємства; влаштовувати наради зі своїми головними співробітниками для досягнення єдності управління; не завантажувати себе дрібницями; встановити серед персоналу дух дієвості, ініціативи та свідомості обов'язку.

4. Координування. Координувати - означає узгодити всі операції таким чином, щоб забезпечити функціонування та успіх підприємства. Цей елемент управління покликаний збалансувати різні аспекти діяльності підприємства. 3 цією метою А. Файоль пропонує проводити щотижневі наради начальників служб. Учасники нарад не займаються складанням плану, а стежать за його виконанням в існуючих умовах. У результаті таких нарад кожен структурний підрозділ уточнює, що йому потрібно робити, відбувається узгодження дій між підрозділами.

5. Контроль. Контроль полягає у перевірці, чи все протікає згідно 3 програмою, згідно з наказами та встановленими принципами. Метою контролю є виявлення слабких сторін і помилок, щоб можна було їх виправити й уникнути повторення. Контроль зачіпає все - персонал, обладнання, товарно-матеріальні цінності, фінансові ресурси, робочі операції і т. д. На думку А. Файоля, для того щоб контроль був дійовим, потрібно, щоб він був проведений вчасно й супроводжувався санкцією. Не менш важливо також, щоб його висновки були своєчасно розглянуті і враховані в подальшій діяльності. Файоль зазначав, що контроль вимагає неослабної уваги й часто великого мистецтва. Можна сказати, що контроль пов'язує всі елементи адміністрування й завершує круговий цикл управлінської діяльності.

Таким чином, усі елементи - передбачення, організація, розпорядництво, координація і контроль - $є$ обов'язковою частиною управлінського процесу. Всі вони розглядаються Файолем не як окремі, виконувані незалежно одна від одної дії, а як невід'ємні складові діяльності керівника. Випадання хоча б одного із них призводить до порушення механізму управління. Всі елементи управління точно вивірені, суворо структуровані та є основою теорії культури адміністрування.

До числа найбільш відомих послідовників А. Файоля можна віднести: Л. Гулика, Л. Урвіка, Дж. Муні й А. Рейлі.

Американський дослідник Лютер Гулик у своїй статті «Нотатки 3 теорії організації», що відкриває збірку «Доповіді про науку управління» (1937р.), розширив функції адміністрації Файоля, виділивши сім функцій 
керівника вищої ланки: планування, організація, управління персоналом, керівництво, координація, звітність, бюджетування. Таким чином, три елемента адміністративної діяльності, такі як планування, організація і координація, були запозичені з теорії Файоля; поняття «розпорядництво» було замінено поняттям «керівництво»; замість функції «контроль» 3'явилися такі напрямки діяльності, як складання бюджету та звітність; із функції «організація» була виділена функція «управління персоналом».

На думку Л. Гулика, «якщо ці сім елементів можуть бути обов'язками керівника вищої ланки, значить, вони можуть бути перетворені на окремі підрозділи» (Gulick, 1937, p. 43). Необхідність та можливість їх створення визначається розміром підприємства. У більш пізніх роботах Гулик додав ще один елемент - «оцінка» (Gulick, 1948).

Л. Гулик виділив два способи координації: 1) за допомогою розпоряджень, які йдуть від верхніх структур до нижніх; 2) за допомогою ідей, розумної цілеспрямованості в думках і бажаннях тих, хто працює разом як команда, щоб кожен сам добровільно хотів узгоджувати своє завдання зі спільною справою. Водночас він визначив обмежуючі фактори координації: розмір і час; масштаб контролю; можливості єдиноначального управління; технічна ефективність.

В основу розподілу функцій можуть бути покладені різні критерії. На думку Гулика, виробничі одиниці можуть об'єднуватися за чотирма ознаками, які роблять різний вплив на координуючу функцію: 1) за метою адміністративної діяльності; 2) за процесом; 3) за людьми або предметами; 4) за місцем перебування. Якщо діяльність підрозділу всередині організації визначається більш ніж одним із перерахованих принципів, то виникає небезпека збільшення розбіжностей між підрозділами, особливо там, де відбувається перетин їх повноважень. Тому завдання керівника полягатиме в ослабленні цих протиріч із метою забезпечення стабільності компанії.

Також Л. Гуликом було виділено десять принципів організації: поділ праці, спеціалізація; департаменталізація на основі мети, процесу, місця; координація за допомогою ієрархії, ідеї, комісій; децентралізація; єдність командування; штаб і лінія; делегування; діапазон управління.

Хоч основну увагу Гулик приділяв розробці цілісної управлінської теорії, він дійшов висновку про те, що всебічно розробленої теорії управління так і не існує. Те, що було замість неї, він називав «більш-менш достовірними й частково підтвердженими припущеннями» (Gulick, 1937, p. 45), а не доведеною теорією. А це свідчить про те, що менеджмент більшою мірою $є$ мистецтвом, ніж наукою.

Значний внесок у формування теорії адміністративної культури менеджменту здійснили американські вчені Джеймс Муні і Алан Рейлі. У праці «Прогресивна індустрія» (1931р.) і другому, більш повному, виданні цієї праці, що вийшло в 1939 р. під назвою «Принципи організації», вони дали визначення поняття «організація». На їхню думку, 
організація є формою об’єднання людей для досягнення спільної мети. На основі аналізу еволюції різних організаційних форм вони дійшли висновку, що для людства характерна схильність до організаційної діяльності, в спільній діяльності люди досягають більшого ефекту, ніж поодинці. Тому організація - це універсальне явище: «Вік організації дорівнює віку людського суспільства» (Mooney \& Reiley, 1931, p. 39).

На думку Дж. Муні й А. Рейлі, організаційна структура починається там, де двоє або більше людей об'єднують свої зусилля для досягнення поставленої мети. Однак вони особливо підкреслювали, що сама по собі комбінація людей і мети ще не становить організаційну структуру. Цілі організації співвідносяться у них із концепцією доктрини, яка, крім визначення мети, включає процедури ії досягнення. Досягнення ж спільної мети вимагає взаєморозуміння всіх членів організації. Тому обов'язком вищого керівництва має стати забезпечення таких умов, за яких призначення організації усвідомлюється ії членами. Таким чином, у рамках теорії адміністративної культури відбувся перехід від управління за завданнями до управління за цілями.

У праці «Прогресивна індустрія» увага акцентується на трьох принципах (Mooney \& Reiley, 1931):

1. Координація. «Координація - це впорядкована організація групових зусиль із метою забезпечення єдності дій для досягнення спільної мети» (р. 210). Вона досягається не тільки за рахунок єдиноначальності, а й за рахунок солідарності працівників. Відповідно до підходу Муні та Рейлі, координація виступає першим і найважливішим принципом організації, оскільки потенційно містить у собі всі інші.

2. Ієрархія. Принцип ієрархії або вертикального поділу праці вказує на те, що влада й повноваження повинні зростати пропорційно одне одному. Кожен службовець повинен бути пов'язаний із керівником усієї організації чітко визначеною владною вертикаллю, якою надходять розпорядження (р. 251). Водночас Муні та Рейлі висловлювались про необхідність делегування повноважень. У протилежному випадку керівник прирікає себе на виконання надмірного кола обов'язків, що знижуватиме ефективність його праці. У той же час зайве делегування може призвести до відмови від влади та відповідальності й може підірвати основу єдиноначальності.

3. Функціональність. Цей принцип указує на важливість спеціалізації у виділенні підрозділів і ролей. Функціональному принципу підпорядковується горизонтальний поділ праці, при якому завдання розподіляються відповідно до різних обов'язків.

Згодом у книзі Муні та Рейлі «Принципи організації» розглядається ще один принцип організації (Mooney \& Reiley, 1939):

4. Лінійний і штабний персонал. Представники лінійного персоналу пов'язані один з одним відносинами «керівник - підлеглий», тоді як штабні - виконують обов'язки консультантів та радників. Лінійний 
персонал - це ті, чиї позиції входять до складу ієрархічної вертикалі, на відміну від пов'язаних із нею менш жорстко штабістів. Штабні служби існують як допоміжні щодо лінійного персоналу (р. 137).

Дж. Муні й А. Рейлі були переконані в тому, що виведені ними логічним шляхом принципи організації подібні фізичним законам.

Вагомий внесок у систематизацію теорії культури адміністративного менеджменту зробив англійський вчений Ліндал Урвік. Найзначимішою в цьому відношенні є його праця «Елементи адміністрації» (1944 р.). У цій роботі він одним із перших зробив спробу синтезу й інтеграції принципів адміністрування, сформульованих різними авторами, і довів, що всі вони пов'язані загальної логікою. Основна увага в роботі приділяється формуванню організаційної структури й моделі адміністративного менеджменту. Пропонована Л. Урвіком модель є спробою синтезувати та відтворити на новому рівні запропоновані А. Файолем, Дж. Муні, А. Рейлі та іншими дослідниками адміністративні принципи.

На його думку, спочатку абсолютно неупереджено слід розробити відповідну організаційну структуру, а потім уже здійснити всі необхідні заходи, щоб знайти відповідних людей або добитися їх відповідності структурі (Urwick, 1944, p. 68). Таким чином, Урвік проголошував один із основоположних принципів культури механістичного менеджменту про необхідність відповідності людей організаційній структурі.

Л. Урвік висунув принцип загальної мети, який передбачає, що організація повинна бути побудована таким чином, щоб всі елементи структури прагнули до їі досягнення. 3 цього приводу він писав: «Доти , поки ми не маємо спільних цілей, немає причин для того, щоб люди прагнули до узгодження своїх дій взагалі або щоб хто-небудь намагався ïх координувати» (Urwick, 1944, p. 83). Загальна мета утворює основу для координації зусиль різних відділів й осіб усередині організації.

Важливими елементами ефективної адміністрації, за Урвіком, $є$ принципи єдиноначальності, делегування й застосування трьох методів створення функціональних підрозділів: унітарний (кожна служба працює у своєму регіоні або зі своїм списком клієнтів), серійний (кожна служба відповідальна за одну з операцій у загальному технологічному процесі) або суб'єктний (служби групуються навколо окремих людей, що володіють необхідною спеціалізацією і можливостями).

Л. Урвік вважав, що для підвищення ефективності управління вищі менеджери повинні неухильно дотримуватися принципу відповідності влади й відповідальності. Також, як і більшість представників адміністративної культури, він розглядав принцип діапазону контролю. На його думку, жоден керівник не може безпосередньо контролювати більше 5-6-ти підлеглих, робота яких взаємозалежна. Конкретна межа залежить від рівня керівництва - на верхніх рівнях це число не повинно перевищувати три, в той час як на нижніх їх може бути вдвічі більше. 
Досить багато уваги Л. Урвік приділяв аналізу специфіки управлінської діяльності та її відмінності від інженерно-технічної. На його думку, керівник повинен володіти знаннями в галузі управління виробництвом і доповнювати їх загальною технічною підготовкою.

Третім напрямом у культурі механістичного менеджменту є бюрократична система управління, якою пронизані практично всі сфери життєдіяльності суспільства. Вона грунтується на раціональному, безособовому управлінні, використанні формальних засобів (правил, процедур), які не схильні до суб' єктивізму менеджера. Існування бюрократичної культури управління передбачає наявність стабільного середовища, жорсткої ієрархії, раціональних структур й індивідів, які беззаперечно виконують розпорядження та відповідають запропонованим їм ролям. Жодні відступи від формально встановлених процедур і правил неприпустимі.

У зв'язку з тим, що бюрократична культура управління детально описана у статті «Еволюція теорії менеджменту: від бюрократії до адхократії», яка автором (Коваленко, 2018) опублікована в попередньому випуску цього журналу, залишається тільки додати, що в основі цього напряму культури менеджменту, як і у двох інших (культура наукової організації праці та управління; культура адміністративного менеджменту), єдина, спільна основа - механіцизм, що, з одного боку, забезпечує високу ефективність їх застосування в умовах індустріалізму, а, з іншого, в умовах становлення постіндустріального суспільства, коли стабільність порушилася, бюрократія виявилася нездатною до існування в наддинамічному середовищі.

\section{4. Висновки та обговорення результатів Conclusions and discussion of results}

Дослідження феномену механістичного менеджменту в контексті культурно-історичної думки, яке спрямовувалося на виявлення базових детермінант генезису та формування основних напрямів розвитку цієї управлінської культури, дозволило дійти таких висновків:

1. Об'єктивними передумовами становлення культури механістичного менеджменту послужили: по-перше, наука Нового часу і механіцизм, що випливає з картини світу Ньютона - уявлення будь-якої реальності як машини, а також атомізм, раціоналізм і соціальний дарвінізм як «природний закон» про міжвидову боротьбу за існування; по-друге, протестантська етика, яка виправдовувала діяльність, спрямовану на наживу й накопичення багатств поза розумними потребами; по-третє, політекономія, яка представила господарство у вигляді машини, що діє за законами ньютонівської механіки; по-четверте, великі науково-технічні відкриття, що вимагали нових форм та способів організації виробництва.

2. На фоні цього сформувалися й отримали теоретичне обгрунтування три самостійних напрями культури механістичного менеджменту: куль- 
тура наукової організації праці та управління; адміністративна культура; бюрократична культура. Їх об’єднує спільний методологічний підхід до розгляду процесів управління, а саме механіцизм.

3. Засновники культури наукової організації праці та управління, будучи інженерами-механіками, перенесли свої знання про діяльність технічних механізмів у сферу управління. Саме технічна освіта засновників цього напряму визначила його специфіку. Вони вважали, що, грунтуючись на спостереженнях і вимірах трудових процесів, використовуючи логіку й аналіз, можна значно вдосконалити багато робочих операцій та домогтися найефективнішого їх виконання. Так на рубежі XIX-XX ст. у США з'явилася культура управління, заснована на інженерних розрахунках і дослідах.

4. Із розвитком промисловості у перші десятиліття XX ст. в Європі виникла культура адміністративного менеджменту, засновниками і популяризаторами якої були вже не тільки інженери, а також, частково, й економісти. Відмінності цієї культури, порівняно з попередньою, полягають у наступному: організація розглядається не чисто механістично, а з елементами подоби живого організму; раціоналізації підлягає переважно соціальна структура організації, а не матеріальна; людина вважається первинним елементом виробництва, а не одним із його елементів; основний акцент робиться на діяльності апарату управління, виконанні ним функцій загального керівництва, а не на діяльності робітника й цеховому виробництві.

5. Бюрократія, порівняно з іншими напрямами культури механістичного менеджменту, має набагато тривалішу історію. Однак їі наукове осмислення як основної форми організації життєдіяльності суспільства розпочалося також тільки в епоху індустріалізму. Ця культура менеджменту грунтується на жорсткій ієрархії, раціональному, безособовому управлінні, використанні формальних засобів, які не схильні до суб' єктивізму керівника.

Незважаючи на те, що суспільство вступило в постіндустріальну еру, вказані напрями культури механістичного менеджменту не втрачають своєї актуальності. На сьогоднішньому етапі здійснюються спроби корегування механістичних концепцій шляхом їх теоретичної добудови, ув'язування й адаптування до нових організаційних реалій.

Наукова новизна одержаних результатів полягає у виявленні об'єктивних передумов, які спричинили виникнення культури механістичного менеджменту, а також в узагальненні особливостей основних напрямів цієї культури управління в умовах індустріального суспільства.

Практичне значення результатів дослідження вбачається у розширенні уявлень про теорію та історію світової культури, включивши в них раніше практично не досліджувані в культурно-історичному контексті ідеї механістичного менеджменту.

Перспективами подальших наукових розвідок у цьому напрямі може бути розроблення способів інтеграції вищерозглянутих трьох напрямів механістичного менеджменту в єдину концепцію, придатну для застосування в нових умовах розвитку суспільства. 


\section{Література}

Бэкон Ф. Сочинения : в 2-х т. Пер. с англ. Москва : Мысль, 1978. Т. 2. $576 \mathrm{c}$.

Вебер М. Протестантская этика и дух капитализма. Пер. с нем. Москва : Директ-Медиа, 2016. 178 с.

Вебер М. Хозяйство и общество. Пер. с нем. Москва : Высшая школа экономики, 2010. 456 с.

Гайденко П. П. Научная рациональность и философский разум. Москва : Прогресс-Традиция, 2003. 528 с.

Гейзенберг В. Избранные труды. Пер. с нем. Москва : Эдиториал, 2001. $616 \mathrm{c}$.

Гоббс Т. Левіафан, або Суть, будова і повноваження держави церковної та цивільної. Пер. з англ. Київ : Дух і Літера, 2000. 600 с.

Декарт Р. Рассуждение о методе. Пер. с фр. Москва : Академический проект, 2017. 205 с.

Друкер П. Управление в обществе будущего. Пер. с англ. Москва : Вильямс, 2007. $320 \mathrm{c}$.

Дункан Дж. Основополагающие идеи в менеджменте. Пер. с англ. Москва : Дело, 1996. 420 c.

Кант И. Критика чистого разума. Пер. с нем. Москва : Эксмо, 2016. 784 с.

Коваленко Є. Я. Еволюція теорії менеджменту: від бюрократії до адхократії. Вісник Київського національного університету культури і мистецтв. Серія: Менеджмент соиіокультурної діяльності. 2018. Вип. 2. С. 26-62.

Лейбниц Г. Сочинения : в 4-х т. Пер. с нем. Москва : Мысль, 1983. Т. 1. $636 \mathrm{c}$.

Мартинишин Я. М., Коваленко С. Я. Смисли в культурі управління. Вісник Національної академії керівних кадрів культури і мистецттв. 2017. № 4. С. 26-31.

Мартинишин Я. М., Коваленко Є. Я. Формування сучасної системи управління життедіяльністю суспільства. Вісник Київського наиіонального університету культури і мистеитв. Серія: Менеджмент соиіокультурної діяльності. 2018а. Вип. 1. С. 7-24.

Мартинишин Я. М., Коваленко Є. Я. Мистецтво управління й освітні технології підготовки менеджерів соціокультурної діяльності. Біла Церква : Вид. Пшонківський О. В., 2018b. 374 с.

Мертон Р. Бюрократическая структура и личность. Социальная теория $и$ социальная структура. Пер. с англ. Москва : АСТ, 2006. С. 323-337.

Милль Дж. Основы политической экономии с некоторыми приложениями к социальной философии. Пер. с англ. Москва : Эксмо, 2007. 1040 с.

Минцберг Г. Создание эффективной организации. Пер. с англ. СанктПетербург : Питер, 2011. 502 с.

Ньютон И. Математические начала натуральной философии. Пер. с лат. Москва : Наука, 1989. 688 с.

Сенге П. Преображение. Потенциал человека и горизонты будущего. Пер. с англ. Москва : Олимп-Бизнес, 2014. 304 с. 
Сен-Симон А. Сочинения : в 2-х т. Пер. с фр. Москва : АСТ, 2015. Т. 1. $956 \mathrm{c}$.

Смит А. Исследование о природе и причинах богатства народов. Пер. с англ. Москва : Эксмо, 2016. 1056 с.

Тейлор Ф. У. Управление фабрикой. Пер. с англ. Москва : Контроллинг, 1992. $152 \mathrm{c}$.

Файоль А. Общее и промышленное управление. Пер. с фр. Москва : Контроллинг, $1992.112 \mathrm{c}$.

Федюкин В. К. История техники и технологий. Москва : Политехника, 2007. $416 \mathrm{c}$.

Флорида Р. Большая перезагрузка. Пер. с англ. Москва : Классика XXI, 2012. $240 \mathrm{c}$.

Форд Г. Моя жизнь, мои достижения. Пер. с англ. Москва : АСТ, 2014. $352 \mathrm{c}$.

Babbage Ch. On the Economy of Machinery and Manufactures. Cambridge : Cambridge university press, 2009. $343 \mathrm{p}$.

Downs A. Inside Bureaucracy. Boston : Little, Brown, Inc., 1967. 292 p.

Emerson H. The twelve principles of efficiency. New York : The Engineering magazine, $1912.423 \mathrm{p}$.

Gantt H. L. Industrial Leadership. New York : Nabu Press, 2014. 166 p.

Gantt H. L. Organizing for Work. New York : Productivity Press, 2017. 120 p.

Gantt H. L. Studies of workers to skills of industrial labour and collaboration. New York : Productivity Press, 2016. 148 p.

Gilbreth F. B. Motion Study. New York : Hard Press Publishing, 2013. 228 p.

Gilbreth F. B., Gilbreth L. M. Applied Motion Study. New York : Filiquarian Legacy Publishing, 2012. $186 \mathrm{p}$.

Gilbreth F. B., Gilbreth L. M. Fatigue Study. New York : Forgotten Books, 2010. 254 p.

Gouldner A. Patterns of Industrial Bureaucracy. Glencoe : The Free Press, 1954. $282 \mathrm{p}$.

Grozier M. Le Phenomene bureaucratique. Paris : Ed. du Seuil, 1963. 234 p.

Gulick L. Administrative Reflections from World War II. Tuscaloosa : University of Alabama Press, 1948. $139 \mathrm{p}$.

Gulick L. Notes on the Theory of Organization. Papers on the Science of Administration. New York : Institute of Public Administration, 1937. P. 3-45.

Hamel G. The Future of Management. Boston : Harvard Business School Press, 2007. $255 \mathrm{p}$.

Marshall A. Elements of Economics of Industry. London : Forgotten Books, 2015. $448 \mathrm{p}$.

Mooney J., Reiley A. Onward Industry!: The Principles of Organization and Their Significance to Modern Industry. New York : Harper \& Brothers, $1931.564 \mathrm{p}$.

Mooney J., Reiley A. The principles of organization. New York : Harper \& Brothers, 1939. $223 \mathrm{p}$.

Owen R. Outline of the Rational System of Society. London : Nabu Press, 2015. $128 \mathrm{p}$. 
Pink D. A whole new mind why right brainers will rule the future. New York : Riverhead Books, 2015. 329 p.

Taylor F. W. A Piece-Rate System. 1896. URL: http:/wps.prenhall.com/wps/ media/objects/107/109902/ch17_a3_d2.pdf (дата звернення : 09.01.2019).

Taylor F. W. The Principles of Scientific Management. New York : Harper \& Brothers, 1997. 144 p.

Trentowski B. Stosunek filozofii do cybernetyki czyli sztuki rządzenia narodem. Poznań : Żupański, 1843. 268 s.

Ure A. The Philosophy Manufactures. London : Charles Knight, 1835. 480 p.

Urwick L. The elements of administration. New York : Harper \& Brothers, 1944. $132 \mathrm{p}$.

Стаття надійшла до редакції 09.01.2019

\section{References}

Babbage, Ch. (2009). On the Economy of Machinery and Manufactures. Cambridge: Cambridge university press.

Bacon, F. (1978). Sochineniia [Works]. (Trans. in Eng.). (Vol. 2). Moscow: Mysl' (in Russ.).

Descartes, R. (2017). Rassuzhdenie o metode [Discourse on method]. (Trans. in Fr.). Moscow: Akademicheskii proekt (in Russ.).

Downs, A. (1967). Inside Bureaucracy. Boston: Little, Brown, Inc.

Drucker, P. (2007). Upravlenie v obshchestve budushchego [Managing in the Next Society]. (Trans. in Eng.). Moscow: Vil'iams (in Russ.).

Duncan, J. (1996). Osnovopolagaiushchie idei v menedzhmente [Fundamental ideas in management]. (Trans. in Eng.). Moscow: Delo (in Russ.).

Emerson, H. (1912). The twelve principles of efficiency. New York: The Engineering magazine.

Fayol, H. (1992). Obshchee i promyshlennoe upravlenie [General and Industrial Management]. (Trans. in Fr.). Moscow: Kontrolling (in Russ.).

Fediukin, V. K. (2007). Istoriia tekhniki i tekhnologii [The history of engineering and technology]. Moscow: Eksmo (in Russ.).

Florida, R. (2012). Bol'shaia perezagruzka [Big reboot]. (Trans. in Eng.). Moscow: Klassika XXI (in Russ.).

Ford, H. (2014). Moia zhizn', moi dostizheniia [My life, My achievements]. (Trans. in Eng.). Moscow: AST (in Russ.).

Gaidenko, P. P. (2003). Nauchnaia ratsional'nost' i filosofskii razum [Scientific rationality and philosophical mind]. Moscow: Progress-Traditsiia (in Russ.).

Gantt, H. L. (2014). Industrial Leadership. New York: Nabu Press.

Gantt, H. L. (2016). Studies of workers to skills of industrial labour and collaboration. New York: Productivity Press.

Gantt, H. L. (2017). Organizing for Work. New York: Productivity Press.

Geizenberg, V. (2001). Izbrannye trudy [Selected works]. (Trans. in Germ.). Moscow: Editorial (in Russ.).

Gilbreth, F. B. (2013). Motion Study. New York: Hard Press Publishing. 
Gilbreth, F. B., \& Gilbreth, L. M. (2010). Fatigue Study. New York: Forgotten Books.

Gilbreth, F. B., \& Gilbreth, L. M. (2012). Applied Motion Study. New York: Filiquarian Legacy Publishing.

Gouldner, A. (1954). Patterns of Industrial Bureaucracy. Glencoe: The Free Press.

Grozier, M. (1963). Le Phenomene bureaucratique [The Phenomenon of Bureaucracy]. Paris: Ed. du Seuil (in Fr.).

Gulick, L. (1937). Notes on the Theory of Organization. Papers on the Science of Administration. New York: Institute of Public Administration, 3-45.

Gulick, L. (1948). Administrative Reflections from World War II. Tuscaloosa: University of Alabama Press.

Hamel, G. (2007). The Future of Management. Boston: Harvard Business School Press.

Hobbes, T. (2000). Leviafan, abo Sut', budova i povnovazhennia derzhavy tserkovnoi ta tsyvil'noi [Leviathan, or the Nature, structure and powers of state ecclesiastical and civil]. (Trans. Eng.). Kyiv: Dukh i Litera (in Ukr.).

Kant, I. (2016). Kritika chistogo razuma [Critique of pure reason]. (Trans. in Germ.). Moscow: Eksmo (in Russ.).

Kovalenko, Y. Y. (2018). Evoliutsiia teorii menedzhmentu: vid biurokratii do adkhokratii [Evolution of management theory: from bureaucracy to adhocracy]. Visnyk Kyivs'koho natsional'noho universytetu kul'tury $i$ mystetstv. Seriia: Menedzhment sotsiokul'turnoi diial'nosti [Bulletin of Kyiv National University of Culture and Arts. Series in Management of social and cultural activity], 2, 26-62 (in Ukr.).

Leibniz, G. (1983). Sochineniia [Works]. (Trans. in Germ.). (Vol. 1). Moscow: Mysl' (in Russ.).

Marshall, A. (2015). Elements of Economics of Industry. London: Forgotten Books.

Martynyshyn, Y. M., \& Kovalenko, Y. Y. (2017). Smysly v kul'turi upravlinnia [The measures in management culture]. Visnyk Natsional'noi akademii kerivnykh kadriv kul'tury i mystetstv [Herald national academy of managerial staff of culture and arts], 4, 26-31 (in Ukr.).

Martynyshyn, Y. M., \& Kovalenko, Y. Y. (2018a). Formuvannia suchasnoi systemy upravlinnia zhyttiediial'nistiu suspil'stva [Formation of the modern system management of life society]. Visnyk Kyivs'koho natsional'noho universytetu kul'tury i mystetstv. Seriia: Menedzhment sotsiokul'turnoi diial'nosti [Bulletin of Kyiv National University of Culture and Arts. Series in Management of social and cultural activity], 1, 7-24 (in Ukr.).

Martynyshyn, Y. M., \& Kovalenko, Y. Y. (2018b). Mystetstvo upravlinnia j osvitni tekhnolohii pidhotovky menedzheriv sotsiokul'turnoi diial'nosti [Art of management and educational technologies of preparation of managers of social and cultural activity]. Bila Tserkva: Vydavets O. V. Pshonkivskyj (in Ukr.).

Merton, R. (2006). Biurokraticheskaia struktura i lichnost' [Bureaucratic structure and personality]. Sotsial'naia teoriia i sotsial'naia struktura [Social Theory and Social Structure]. (Trans. in Eng.). Moscow: AST, 323-337 (in Russ.). 
Mill, J. (2007). Osnovy politicheskoi ekonomii s nekotorymi prilozheniiami $k$ sotsial'noi filosofii [Principles of political economy with some applications to social philosophy]. (Trans. in Eng.). Moscow: Eksmo (in Russ.).

Mintzberg, H. (2011). Sozdanie effektivnoi organizatsii [Creation of an effective organization]. (Trans. in Eng.). St. Petersburg: Piter (in Russ.).

Mooney, J., \& Reiley, A. (1931). Onward Industry!: The Principles of Organization and Their Significance to Modern Industry. New York: Harper \& Brothers.

Mooney, J., \& Reiley, A. (1939). The principles of organization. New York: Harper \& Brothers.

Newton, I. (1989). Matematicheskie nachala natural'noi filosofii [Mathematical principles of natural philosophy]. (Trans. in Lat.). Moscow: Nauka (in Russ.).

Owen, R. (2015). Outline of the Rational System of Society. London: Nabu Press.

Pink, D. (2015). A whole new mind why right brainers will rule the future. New York: Riverhead Books.

Saint-Simonians, A. (2015). Sochineniia [Works]. (Trans. in Fr.). (Vol. 1). Moscow: AST (in Russ.).

Senge, P. (2014). Preobrazhenie. Potentsial cheloveka i gorizonty budushchego [Transformation. The potential of man and the horizons of the future]. (Trans. in Eng.). Moscow: Olimp-Biznes (in Russ.).

Smith, A. (2016). Issledovanie o prirode i prichinakh bogatstva narodov [An inquiry into the nature and causes of the wealth of nations]. (Trans. in Eng.). Moscow: Eksmo (in Russ.).

Taylor, F. W. (1896). A Piece-Rate System. Retrieved from http://wps.prenhall. com/wps/media/objects/107/109902/ch17_a3_d2.pdf.

Taylor, F. W. (1992). Upravlenie fabrikoi [Management of the factory]. (Trans. in Eng.). Moscow: Kontrolling (in Russ.).

Taylor, F. W. (1997). The Principles of Scientific Management. New York: Harper \& Brothers.

Trentowski, B. (1843). Stosunek filozofii do cybernetyki czyli sztuki rzadzenia narodem [The Relationship of philosophy to Cybernetics it is the art to lead the people]. Poznań: Żupański (in Pol.).

Ure, A. (1835). The philosophy manufactures. London: Charles Knight.

Urwick, L. (1944). The elements of administration. New York: Harper \& Brothers.

Weber, M. (2010). Khoziaistvo i obshchestvo [Economy and society]. (Trans. in Germ.). Moscow: Vysshaia shkola ekonomiki (in Russ.).

Weber, M. (2016). Protestantskaia etika i dukh kapitalizma [The protestant ethic and the spirit of capitalism]. (Trans. in Germ.). Moscow: DirektMedia (in Russ.). 